\title{
PEMANFAATAN LIMBAH MARMER SEBAGAI BAHAN PERKERASAN JALAN PADA CAMPURAN HOT ROLLED SHEET - BINDER COURSE
}

\author{
Ermitha Ambun Rombe Dendo ${ }^{1}$ \\ Harni Eiren Tarru ${ }^{2}$ \\ Staf Pengajar Progdi Teknik Sipil \\ Universitas Kristen Indonesia Toraja
}

\section{INTISARI}

Marmer merupakan salah satu material bahan bangunan yang dipergunakan sebagai bahan pembuat penutup lantai atau yang lebih dikenal dengan nama tegel. Kabupaten Pangkep merupakan salah satu daerah penghasil marmer terbesar di Indonesia.Pabrik pengolahan marmer terus berproduksi dan meninggalkan banyak limbah marmer yang berupa pecahan dengan ukuran yang bervariasi yaitu berbentuk cubical dan beberapa partikel halus. Dengan terus berproduksinya pabrik pengolahan batu marmer maka limbah marmer juga akan terus bertambah.

Bentuk yang cubical dan kekuatan yang cukup diharapkan dapat memberikan suatu keunggulan.Oleh sebab itu, tujuan dari penelitian ini adalah untuk mengetahui apakah limbah pecahan marmer dapat dipergunakan sebagai agregat kasar dalam campuran aspal tipe Lataston. Penelitian ini menggunakan metode penelitian eksperimental murni dan hanya membahas skala penelitian laboratorium campuran Lapis Tipis Aspal beton dengan 5 (lima) variasi agregat kasar dalam campuran yaitu variasi I menggunakan $100 \%$ limbah pecahan marmer dengan KAO $5,8 \%$, variasi II menggunakan 75\% limbah pecahan marmer dengan KAO 5,94\%, variasi III menggunakan $50 \%$ limbah pecahan marmer dengan KAO 6,04\%, variasi III menggunakan 25 $\%$ limbah pecahan marmer dengan KAO 6,27\%, variasi IV menggunakan $25 \%$ limbah pecahan marmer dengan KAO 6,1\%, variasi V menggunakan $100 \%$ limbah pecahan marmer dengan KAO 6,27\%. Semua campuran didasarkan pada metode Marshall menurut persyaratan dan spesifikasi yang ditetapkan oleh Depertemen Pekerjaan Umum (2010). Pengujian campuran dilakukan untuk mengetahui durabilitas dengan lama perendaman $1 / 2$ jam dan 24 jam.

Penelitian menunjukkan bahwa limbah pecahan marmerdapat digunakan sebagai agregat kasar dan secara fisik memenuhi persyaratan yang ditetapkan oleh oleh Depertemen Pekerjaan Umum (2010). Penelitian ini menunjukkan bahwa variasi I memiliki VMA dan VIM paling rendah yaitu sebesar $16,2 \%$ dan 3,7\%. Nilai VMA dan VIM tertinggi dimiliki oleh variasi IV yaitu sebesar $17,3 \%$ dan $5,0 \%$. Nilai stabilitas tertinggi pada perendaman 24 jam diperoleh pada campuran variasi IV $1322 \mathrm{~kg}$.

Berdasarkan penelitian ini diperoleh variasi III dengan menggunakan 50\% limbah pecahan marmer atau kurang dari 50\% secara umum dapat digunakan sebagi bahan alternatif untuk agregat kasar pada campuran Lapis Tipis Aspal Beton (Lataston).

Kata kunci :Limbah Marmer, Lapis Tipis Aspal Beton (Lataston), Marshall Immersion, Stability 


\section{PENDAHULUAN}

Pesatnya pertumbuhan lalu lintas baik jumlah maupun daya angkutnya berdampak pada makin pendeknya umur pelayanan konstruksi jalan. Disisi lain, akibat keterbatasan dana menuntut terjadinya umur rencana pelayanan konstruksi jalan yang lebih panjang sehingga menjadi lebih ekonomis disamping harus tetap memperhatikan faktor keamanan dan kenyamanan bagi pengguna jalan.

Sejalan dengan hal tersebut diperlukan material/bahan konstruksi perkerasan jalan yang berkualitas namun tetap memenuhi persyaratan dan spesifikasi teknis yang ditetapkan oleh Bina Marga.Dengan berlakunya otonomi daerah, pihak pemerintah diharapkan jeli melihat dan memanfaatkan potensi sumber daya alam yang terdapat di daerahnya untuk dapat dikembangkan.Di Sulawesi Selatan banyak terdapat pabrik pengolahan batu kapur/karst menjadi marmer yang digunakan sebagi bahan penutup lantai.Dari pengolahan tersebut menghasilkan limbah berupa potongan yang berbentuk cubical dankeras seperti batu.

Berdasarkan hal tersebut penulis mencoba melakukan penelitian dengan memanfaatkan limbah hasil pengolahan dari pabrik marmer tersebut sebagai bahan alternatif pengganti aggregat konvensional untuk bahan perkerasan jalan.

\section{KAJIAN PUSTAKA}

\subsection{LAPIS TIPIS ASPAL BETON}

Menurut Kementrian Pekerjaan Umum (Bina Marga revisi 2010), lapis tipis aspal beton (lataston) adalah lapisan penutup yang terdiri dari campuran agregat bergradasi senjang, filler dan aspal keras dengan perbandingan tertentu; yang dicampur dan dipadatkan secara panas (dalam suhu tertentu, minimum $124^{\circ} \mathrm{C}$ ), dengan ketebalan padat $2,5 \mathrm{~cm}$ atau $3 \mathrm{~cm}$. Konstruksi perkerasan HRS dalam penggunaanya dibagi menjadi dua kelas yaitu kelas A dan kelas B. Perbedaan kedua konstruksi perkerasan tersebut terdapat pada gradasi agregat yang digunakan, beban lalu lintas dan segi pemakaian. Jenis agregat yang digunakan terdiri dari agregat kasar, agregat halus dan butiran pengisi (filler), sedangkan aspal yang digunakan biasanya jenis aspal keras AC 60-70 dan AC 80- 100.

Pembuatan lapis tipis aspal beton (lataston) bertujuan untuk mendapatkan suatu lapisan permukaan atau lapisan antar pada perkerasan jalan raya yang mampu memberikan sumbangan daya dukung serta berfungsi sebagai lapisan kedap air yang dapat melindungi konstruksi bawahnya.Hot Rolled Sheet bersifat lentur dan mempunyai durabilitas yang tinggi, hal ini disebabkan campuran HRS dengan gradasi timpang mempunyai rongga dalam campuran yang cukup besar, sehingga mampu menyerap jumlah aspal dalam jumlah banyak (7-8\%) tanpa terjadi bleeding. Selain itu, HRS mudah dipadatkan sehingga lapisan yang dihasilkan mempunyai kekedapan terhadapair dan udara tinggi. Kegagalan dini yang sering terjadi di lapangan adalah pada proses penghamparan dan pemadatan karena HRS tidak sepenuhnya murni gapgraded (Bina Marga, 2010). 
Menurut Bina Marga (2010), dua hal yang mempengaruhi campuran lataston yaitu:

a. Gradasi yang benar-benar senjang. Gradasi senjang dapat diperoleh dengan mencampurkan pasir halus dengan agregat pecah mesin. Batas bahan bergradasi senjang pada lataston terletak diantara bahan yang lolos saringan No. $8(2,36 \mathrm{~mm})$ tetapi tertahan saringan No. 30 $(0,600 \mathrm{~mm})$, yang menggunakan suatu campuran agregat kasar dan agregat halus.

b. Rongga udara pada kepadatan membal (refusal density) harus memenuhi ketentuan yang ditunjukan oleh pedoman.

Campuran pada penelitian ini adalah Hot Rolled Sheet (HRS) yang memiliki gradasi senjang. Ketentuan sifat-sifat campuran Lataston mengacu ada Bina Marga (2010) yang terlihat pada tabel berikut :

\begin{tabular}{|l|l|c|}
\hline No. & \multicolumn{1}{|c|}{ Spesifikasi } & Nilai \\
\hline 1. & Jumlah tumbukan & $2 \times 75$ \\
\hline 2. & Densitas & - \\
\hline 3. & VITM & $3-6 \%$ \\
\hline 4. & VFMA & $\geq 68 \%$ \\
\hline 5. & Stabilitas & $\geq 800 \mathrm{~kg}$ \\
\hline 6. & Flow & $\geq 3 \mathrm{~mm}$ \\
\hline 7. & Marshal quotient & $\geq 250 \mathrm{~kg} / \mathrm{mm}$ \\
\hline
\end{tabular}

Sumber : Kementerian Pekerjaan Umum. Direktorat Jenderal Bina Marga, Spesifikasi Umum 2010 (Revisi 3)

\subsection{Bahan Penyusun Perkerasan}

Bahan penyusun perkerasan jalan adalah aspal, agregat, bahan pengisi (filler) serta karet sebagai additive.Hasil yang baik dan berkualitas dalam menghasilkan perkerasan jalan dapat diperoleh jika menggunakan bahan-bahan dengan kualitas baik. Berikut adalah penjelasan bahan penyusun perkerasan :

\subsubsection{Aspal}

Aspal berasal dari minyak mentah (crude oil) dan ada juga yang berasal dari sisa organisme mahkluk hidup dan tumbuhan dari masa lampau yang sudah lama tertimbun oleh batu tanah, sehingga menjadi sendimen dan terakumulasi dalam lapisan-lapisan tanah. Sedimen tersebut lama kelamaan akan terproses menjadi minyak mentah yang menjadi senyawa dasar hydrocarbon. Aspal yang biasa ditemukan berasal dari minyak, tetapi ada juga aspal yang berasal dari bahan alam seperti asbuton atau dikenal dengan istilah mineral. 


\subsubsection{Agregat}

Agregat biasanya berasal dari batu pecah, krikil, pasir ataupun komposisi lainnya, baik hasil alam (natural aggregate), hasil pengolahan (manufactured aggregate) maupun agregat buatan (syntetic aggregate) yang digunakan sebagai bahan utama penyusun perkerasan jalan.

Agregat yang biasa dipakai dalam campuran lapis tipis aspal beton harus bisa memenuhi persyaratan yang telah ditentukan sebagai berikut :

Tabel 2.1 Persyaratan Pemeriksaan Agregat Kasar

\begin{tabular}{|c|c|c|c|c|}
\hline \multicolumn{3}{|c|}{ Pengujian } & Standar & Nilai \\
\hline \multirow{2}{*}{\multicolumn{2}{|c|}{$\begin{array}{l}\text { Kekekalan bentuk agregat } \\
\text { terhadap larutan }\end{array}$}} & \multirow{2}{*}{$\begin{array}{l}\text { natrium sulfat } \\
\text { magnesium sulfat }\end{array}$} & \multirow{2}{*}{ SNI 3407.2008} & \multirow{2}{*}{$\begin{array}{l}\text { Naks. } 12 \% \\
\text { Naks. } 18 \%\end{array}$} \\
\hline & & & & \\
\hline \multirow{4}{*}{$\begin{array}{l}\text { Abrasi dengan } \\
\text { mesin Los } \\
\text { Angeles }\end{array}$} & \multirow{2}{*}{$\begin{array}{l}\text { Campuran AC } \\
\text { Modifikasi }\end{array}$} & 100 putaran & \multirow{4}{*}{ SNI 2417:2008 } & Maks. $6 \%$ \\
\hline & & 500 putaran & & Naks. $30 \%$ \\
\hline & \multirow{2}{*}{$\begin{array}{l}\text { Semua jenis } \\
\text { campuran aspal } \\
\text { bergradasi lainnya }\end{array}$} & 100 putaran & & Maks. $8 \%$ \\
\hline & & 500 putaran & & Naks. $40 \%$ \\
\hline \multicolumn{3}{|c|}{ Kelekatan agregat terhadap aspal } & SNI 2439:2011 & Mlin. $95 \%$ \\
\hline \multicolumn{3}{|c|}{ Butir Pecah pada Agregat Kasar } & SNI 7619:2012 & $95 / 90^{\circ}$ \\
\hline \multicolumn{3}{|c|}{ Partikel Pipih dan Lonjong } & $\begin{array}{c}\text { ASTM D4791 } \\
\text { Perbandingan 1: } 5\end{array}$ & Maks. $10 \%$ \\
\hline \multicolumn{3}{|c|}{ Material lolos Ayakan No. 200} & SNI 03-4142-1996 & Maks. $2 \%$ \\
\hline
\end{tabular}

Sumber: Kementerian Pekerjaan Umum. Direktorat Jenderal Bina Marga Spesifikasi Umum 2010 (Revisi 3)

Tabel 2.2 Persyaratan Pemeriksaan Agregat Halus

\begin{tabular}{|l|c|c|}
\hline \multicolumn{1}{|c|}{ Pengujian } & Standar & Nilai \\
\hline Nilai Setara Pasir & SNI 03-4428-1997 & Min 60\% \\
\hline Angularitas dengen Uji Kadar Rongga & SNI 03-6877-2002 & Min.45 \\
\hline $\begin{array}{l}\text { Gumpalan Lempung dan Butir-butir } \\
\text { Mudah Pecah dalam Agregat }\end{array}$ & SNI 03-4141-1996 & Maks 1\% \\
\hline Agregat Lolos Ayakan No.200 & SNI ASTM C117:2012 & Maks. 10\% \\
\hline
\end{tabular}

Sumber: Kementerian Pekerjaan Umum. Direktorat Jenderal Bina Marga Spesifikasi Umum 2010 (Revisi 3)

Kemudian gradasi agregat diperoleh dengan pemeriksaan analisis satu set saringan dan dinyatakan dalam persentase yang tertahan dan lolos dalam saringan. 
Tabel 2.3 Spesifikasi Gradasi Agregat HRS

\begin{tabular}{|c|c|c|c|c|c|c|c|c|c|}
\hline \multirow{4}{*}{$\begin{array}{l}\text { Ukunn } \\
\text { Ayskan } \\
\text { (mmin) }\end{array}$} & \multicolumn{9}{|c|}{ \% Berat Yang Lolos terhadap Total Agregat dalam Campuran } \\
\hline & \multicolumn{2}{|c|}{ Latasir (SS) } & \multicolumn{4}{|c|}{ Lataston (IIRS) } & \multicolumn{3}{|c|}{ Laston $(\mathrm{AC})$} \\
\hline & \multirow[b]{2}{*}{ Kelas A } & \multirow[b]{2}{*}{ Ketas B } & \multicolumn{2}{|c|}{ Grodui Srejore? } & \multicolumn{2}{|c|}{ 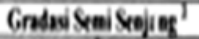 } & \multirow[b]{2}{*}{ WC } & \multirow[b]{2}{*}{$\mathrm{BC}$} & \multirow[b]{2}{*}{ Bax } \\
\hline & & & WC & Bax & WC & Busc & & & \\
\hline 37,5 & & & & & & & & & 100 \\
\hline 25 & & & & & & & & 100 & $90 \cdot 100$ \\
\hline 10 & In & $19 m$ & 100 & 10 & 190 & 10 & 10 & $Q 6 \cdot 100$ & 96.00 \\
\hline 125 & & & 90.100 & 90.100 & 87.100 & 90.100 & $90 \cdot 100$ & 75.90 & 60.78 \\
\hline 9,5 & $90 \cdot 100$ & & 75.15 & $65 \cdot 90$ & 55.88 & $55 \cdot 70$ & $n \cdot 90$ & 66.82 & 52.71 \\
\hline 4,75 & & & & & & & 3.69 & 46.64 & $33 \cdot 4$ \\
\hline 236 & & 75.100 & $50-72^{\prime}$ & 35.53 & $50-62$ & 32.4 & 33.53 & $30 \cdot 49$ & 23.41 \\
\hline 1,18 & & & & & & & $21 \cdot 40$ & 18.38 & 13.30 \\
\hline 0,600 & & & 35.60 & 15.35 & $20-45$ & $15 \cdot 35$ & 14.30 & 12.28 & 10.22 \\
\hline 0,300 & & & & & $15-33$ & 5.35 & $9 \cdot 22$ & 7.20 & 6.15 \\
\hline 0,150 & & & & & & & 6.15 & 5.13 & 4.10 \\
\hline 0,075 & 10.15 & 8.13 & 6.10 & 2.9 & $6-10$ & 4.8 & 4.9 & 4.8 & 3.7 \\
\hline
\end{tabular}

Sumber: Kementerian Pekerjaan Umum. Direktorat Jenderal Bina Marga Spesifikasi Umum 2010 (Revisi 3)

\subsubsection{Filler}

Dilihat dari pengertiannya, bahan pengisi atau filler merupakan bagian dari agregat, maksudnya filler pada susunan gradasi ini adalah material yang lolos ayakan No.200 (0.075 $\mathrm{mm})$, bahan tersebut tidak kurang dari 75\% dari yang lolos saringan No.30 $(0,600 \mathrm{~mm})$ serta bersifat non plastis. Filler berfungsi untuk mengisi bagian-bagian yang kosong (rongga-rongga atau celah yang terdapat pada sela-sela agregat).Bahan filler dapat berupa abu batu, abu batu kapur atau semen.

\subsection{Parameter Marshall Test}

\subsubsection{Density}

Nilai density adalah parameter yang berfungsi untuk menunjukkan tingkat kepadatan suatu campuran perkerasan agregat dan aspal.Tingkat kepadatan menunjukkan kerapatan campuran yang telah dipadatkan.Semakin besar nilai density, maka kerapatan dan kepadatan campuran semakin baik. Kerapatan dan kepadatan yang baik akan meningkatkan beban besar.

\subsubsection{Void in the mix (VITM)}

VITM adalah persentase antara rongga udara dengan volume total campuran setelah dipadatkan. Semakin kecil nilai VITM maka semakin besar kadar aspal. Nilai VITM yang semakin besar menyebabkan tingkat kelelehan yang cepat (berupa alur dan retak).

\subsubsection{Void filled with asphalt (VFWA)}

VFWA adalah persentase volume rongga yang terdiri dari butir-butir agregat suatu campuran aspal padat, di dalamnya juga terdapat aspal efektif. Rongga aspal yang terisi penuh 
juga meningkatkan persen kadar aspal, maka persen kadar aspal yang mengisi rongga adalah persen kadar aspal maksimum.

\subsubsection{Stabilitas}

Stabilitas adalah kemampuan maksimal suatu benda uji campuran beton aspal menahan beban sampai terjadi kelelehan plastis. Nilai stabilitas akan bertambah dengan naiknya kadar aspal sampai ke batas optimum dan akan mengalami penurunan setelah batas optimum. Hal ini terjadi karena aspal dapat berfungsi sebagai pelicin setelah melebihi batas optimum.

\subsubsection{Flow}

Flow adalah besarnya perubahan (deformasi benda uji) campuran dengan angka kelelehan tinggi serta stabilitas rendah di atas batas maksimum akan cenderung plastis. Campuran dengan angka kelelehan rendah dan stabilitas tinggi dibawah optimum akan menyebabkan benda mudah retak bila diberi beban. Flow dinyatakan dalam satuan panjang.

\subsubsection{Marshall quotient (QM)}

Marshall Quotient adalah perbandingan antara nilai stabilitas dengan flow.Marshall Quotient merupakan indikator dalam menentukan nilai fleksibitas kelenturan terhadap keretakan. Kenaikan fleksibitas disebabkan oleh penambahan kadar aspal dan akan penurunan hingga batas optimum disebabkan oleh berubahnya fungsi aspal sebagai pengikat menjadi pelican. 


\section{METODE PENELITIAN}

Penelitian ini dilakukan di Laboratorium TransportasiTeknik Sipil Fakultas Teknik Universitas Gadjah Mada.Adapun tahapan penelitiandapat dilihat pada gambar 3.1.

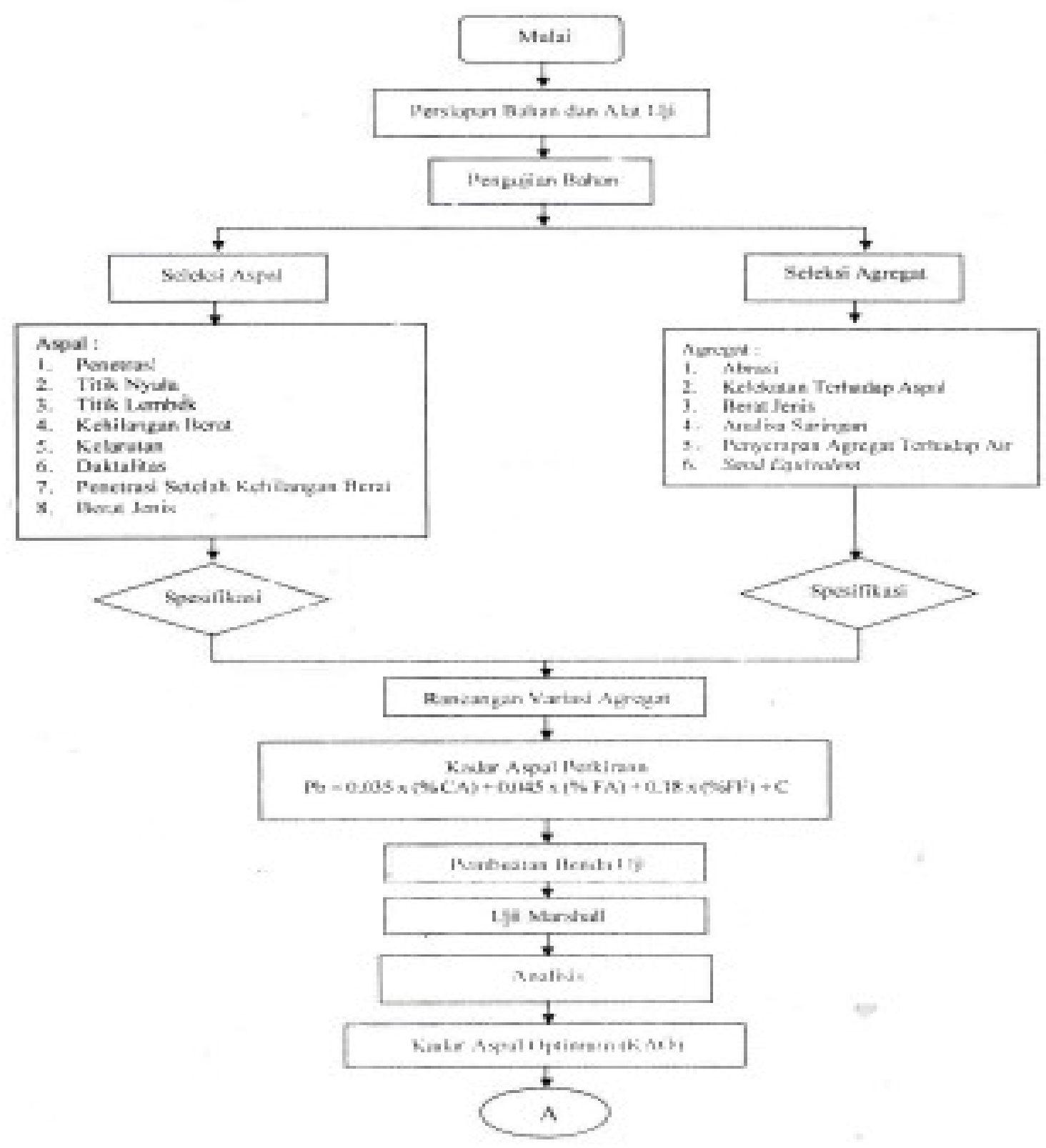




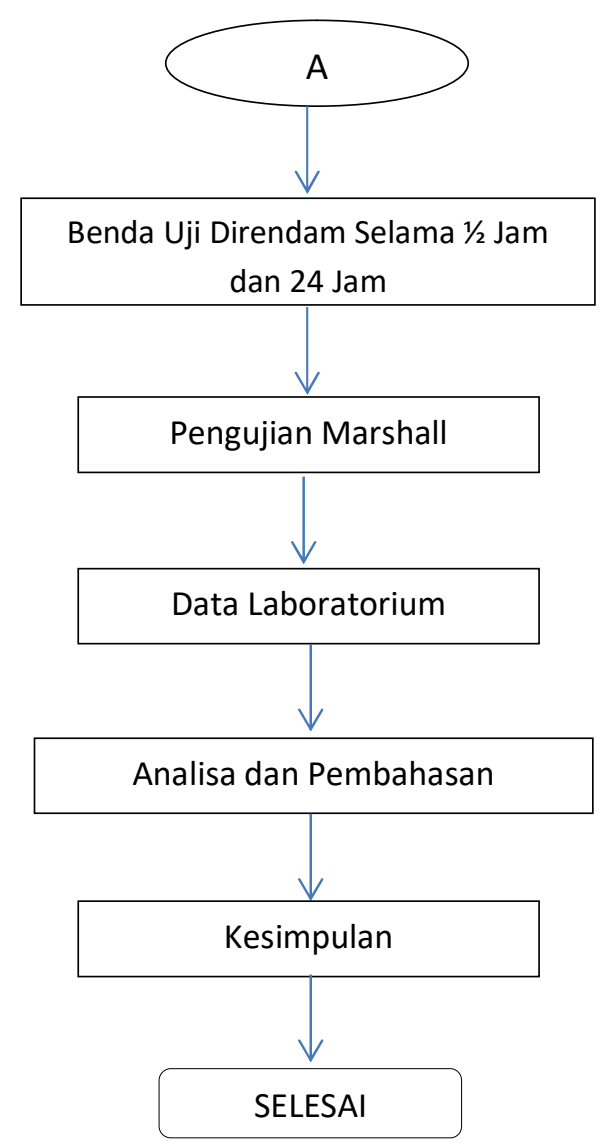

Gambar 3.1 Bagan Alir Penelitian

Material yang digunakan antara lain sebagai berikut :

a. kerikil (batu pecah), pasir dan abu batu diperoleh dari pabrik pemecah batu eks Clereng;

b. limbah batu marmer diperoleh dari Desa Bungoro Kabupaten Pangkep;

c. aspal digunakan adalah jenis aspal padat dengan penetrasi $60 / 70$.

Perencanaan campuran lataston standar ditujukan untuk mendapatkan komposisi campuran,dengan langkah-langkah meliputi : pemilihan dan penentuan sifat agregat, penentuan campurannominal, penentuan proporsi campuran,membuatbenda uji. Pengujian campuran laston standardengan alat Marshall (Marshall Test), ditujukan untuk mendapatkan nilai karakteristik Marshall. Hubungan antara kadar aspal dan nilai karakteristik marshall divisualisasikan dalam bentuk grafik, selanjutnya dihasilkankan kadar aspal optimum.

Campuran lalaston dengan limbah batu marmermenggantikan sebagian agregat kasar dibuat dengan kadar limbah batu marmer secara variatif yaitu $25 \%, 50 \%, 75 \%$ dan $100 \%$ (dibuat berdasarkan kadar aspal optimun campuran lataston standar). Pengujian campuran lataston dengan limbah batu marmer sebagai pengganti sebagian agregat kasar menggunakan alat Marshall, diperoleh nilai karakteristik Marshall. Hubungan antara kadar limbah dan nilai karakteristik Marshall divisualisasikan dalam bentuk grafik, selanjutnya didapatkan kadar 
limbah batu marmer optimum dari campuran lataston dengan limbah batu marmer sebagai pengganti agregat kasar.

\section{HASIL PENELITIAN DAN PEMBAHASAN}

Dalam penelitian ini bahan yang digunakan agregat kasar, agregat halus dan filter.Pemeriksaan dan pengujian dilakukan terhadap ketiga bahan dan campuran ketiganya.

\section{a. Hasil pemeriksaan sifat fisik bahan.}

\section{Hasil pemeriksaan agregat.}

Dari hasil penelitian di laboratorium diperoleh data-data pemeriksaan terhadap agregat kasar, agregat halus dan filter seperti yang tertera pada tabel 4.1.

Tabel 4.1 Hasil pemeriksaan karakteristik agregat kasar.

\begin{tabular}{|c|c|c|c|c|}
\hline No. & Jenis Pemeriksaan & Standar & Hasil & Satuan \\
\hline \multirow[b]{2}{*}{1} & Abrasi batu pecah eks elereng & \multirow[t]{2}{*}{ Maks. 40} & 29,5 & $\%$ \\
\hline & Abrasi limbah pecahan marmer & & 25,0 & $\%$ \\
\hline \multirow[b]{2}{*}{2} & Kelekatan batu pecah terhadap aspal & \multirow[t]{2}{*}{ Min. 95} & 98,0 & $\%$ \\
\hline & Kelekatan limbah pecahan marmer terhadap aspal & & 96,0 & $\%$ \\
\hline \multirow{7}{*}{3} & BJ semua batu pecah & \multirow{7}{*}{$>2,5$} & 2,658 & $\mathrm{gr} / \mathrm{cm}^{3}$ \\
\hline & BJ semua limbah pecahan marmer & & 2,712 & $\mathrm{gr} / \mathrm{cm}^{3}$ \\
\hline & BJ semua agregat halus & & 2,770 & $\mathrm{gr} / \mathrm{cm}^{3}$ \\
\hline & BJbulk batu pecah & & 2,547 & $\mathrm{gr} / \mathrm{cm}^{3}$ \\
\hline & BJbulk limbah pecahan marmer & & 2,691 & $\mathrm{gr} / \mathrm{cm}^{3}$ \\
\hline & BJbulk agregat halus & & 2,650 & $\mathrm{gr} / \mathrm{cm}^{3}$ \\
\hline & BJfilter debu batu & & 2,722 & $\mathrm{gr} / \mathrm{cm}^{3}$ \\
\hline \multirow{3}{*}{4} & Absorpsi batu pecah & \multirow{3}{*}{$<3$} & 1,640 & $\%$ \\
\hline & Absorpsi limbah pecahan marmer & & 0,294 & $\%$ \\
\hline & Absorpsi agregat halus & & 1,635 & $\%$ \\
\hline 5 & Sand Equivalent & Min. 50 & 80,40 & $\%$ \\
\hline
\end{tabular}


Dari hasil pemeriksaan laboratorium terhadap sifat fisik bahan dapat disimpulkan bahwa bahan - bahan akan yang digunakan sebagai agregat dalam penelitian ini memenuhi spesifikasi dan layak untuk digunakan sebagai bahan perkerasan jalan.

\section{Hasil pemeriksaan aspal}

Aspal yang digunakan adalah aspal keras AC 60/70 yang diproduksi oleh Pertamina.Dari hasil di laboratorium, diperoleh data-data terhadap yang dapat dilihat pada Tabel 4.2.

Tabel 4.2 Hasil pemerikasaan karakteristik aspal

\begin{tabular}{|c|c|c|c|c|}
\hline No & Jenis pemeriksaan & Spesifikasi & Hasil & Satuan \\
\hline 1 & Penetrasi $25^{\circ} \mathrm{C}, 100$ gr, 5 detik & $60-79$ & 63,80 & $0,1 \mathrm{~mm}$ \\
\hline 2 & Titik lembek & $48-58$ & 48,25 & ${ }^{\circ} \mathrm{C}$ \\
\hline 3 & Titik nyala & Min 200 & 340 & ${ }^{\circ} \mathrm{C}$ \\
\hline 4 & Daktilitas & Min 100 & $>100$ & $\mathrm{Cm}$ \\
\hline 5 & Berat jenis & Min 1,0 & 1,030 & $\mathrm{Gr} / \mathrm{cc}$ \\
\hline 6 & $\begin{array}{lll}\text { Kelarutan } & \text { dalam } & \text { Trichlor } \\
\text { Ethylen } & & \end{array}$ & Min 99 & 99,455 & $\%$ \\
\hline 7 & Kehilangan berat & Max 0,88 & 0,0834 & $\%$ \\
\hline 8 & $\begin{array}{l}\text { Penetrasi setelah kehilangan } \\
\text { berat }\end{array}$ & Min 54 & 92,50 & $\%$ \\
\hline 9 & $\begin{array}{l}\text { Daktilitas setelah kehilangan } \\
\text { berat }\end{array}$ & Min 50 & $>100$ & $\%$ \\
\hline
\end{tabular}

Dari hasil pemeriksaan laboratorium terhadap sifat aspal dapat disimpulkan bahwa aspal tipe AC 60/70 akan yang digunakan sebagai bahan pengikat agregat dalam penelitian ini memenuhi spesifikasi dan layak untuk digunakan sebagai bahan perkerasan jalan.

\section{b. Karakteristik Marshall campuran HRS-BC pada kondisi KAO}

Hasil uji tekan Marshall (Marshall compression) berupa karakteristik volumetric campuran agregat-aspal panas dan durabilitas campuran (Marshall immersion ) yang menggunakan variasi campuran limbah pecahan marmer dan batu pecah pada agregat kasar pada kondisi kadar aspal optimum seperti density, voids filled with asphalt, voids in mix dan voids in mineral agregat, stability, flow dan Marshall quotlent dengan berbagai variasi campuran disajikan dalam bentuk tabel. 


\section{Data karakteristik volumetric campuran}

Data hasil pengujian Marshall compression dengan menggunakan kadar aspal optimum disajikan pada Tabel 4.3. Nilai-nilai tersebut merupakan rata-rata dari hasil pengujian terhadap 3 benda uji ( triplo) pada masing-masing variasi campuran.

Tabel 4.3 Hasil volumetric campuran pada kondisi KAO.

\begin{tabular}{|c|c|c|c|c|c|}
\hline Variasi & KAO & $\begin{array}{c}\text { Density } \\
\left(\mathbf{g r} / \mathbf{c m}^{\mathbf{3}}\right)\end{array}$ & $\begin{array}{c}\text { VMA ( }) \\
\mathbf{\%})\end{array}$ & $\begin{array}{c}\text { VIM } \\
\mathbf{( \% )}\end{array}$ & $\begin{array}{c}\text { VFA } \\
\mathbf{( \% )}\end{array}$ \\
\hline I & 5,8 & 2,831 & 16,2 & 3,7 & 77,5 \\
\hline II & 5,96 & 2,344 & 17,0 & 4,5 & 73,4 \\
\hline III & 6,04 & 2,326 & 17,1 & 4,7 & 72,3 \\
\hline IV & 6,1 & 2,313 & 17,3 & 5,0 & 71,1 \\
\hline V & 6,27 & 2,320 & 17,1 & 4,5 & 75,1 \\
\hline
\end{tabular}

\section{a. Kepadatan ( Density )}

Nilai kepadatan menunjukkan besarnya dearajat kepadatan suatu campuran setelah dipadatkan atau perbandingan anatara berat terhadap volume campuran. Tingkat kepadatan suatu campuran dipengaruhi oleh gradasi agregat, kadar aspal, diperoleh nilai kepadatan masing-masing sebesar 2,381 gr/ $\mathrm{cm}^{3}, 2,344 \mathrm{gr} / \mathrm{cm}^{3}, 2,326 \mathrm{gr} / \mathrm{cm}^{3}, 2,313 \mathrm{gr} / \mathrm{cm}^{3}$ dan 2,320 $\mathrm{gr} / \mathrm{cm}^{3}$. Hal ini disebabkan oleh adanya perubahan komposisi pada masing-masing campuran pada agregat kasar. Pada campuran I, agregat kasar yang digunkan adalah 100\% limbah pecahan marmer dan selanjutnya dilakukan pengurangan komposisi limbah pecahan marmer sebesar $25 \%$ pada tiap campuran hingga mencapai $0 \%$ seperti yang terdapat pada campuran variasi $\mathrm{V}$. Dari penjelasan sebelumnya diketahui bahwa limbah pecahan marmer mempunyai pori dan daya serap ( absorption ) yang kecil sehingga aspal yang diserap juga sedikit dan hanya melekat pada permukaan agregat saja. Dengan adanya penurunan persen limbah pecahan marmer dan peningkatan persen batu pecah akan memberikan peningkatan jumlah pori dalam masingmasing variasi campuran. Kondisi tersebut menyebabkan kepadatan campuran menurun, namun sebaliknya yang terjadi pada campuran variasi V. Pada variasi V, terjadi kenaikan nilai kepadatan sebab dimungkinkan adanya degradasi agregat pada campuran.Seperti diketahui bahwa batu pecah memiliki abrasi yang lebih tinggi dari pecahan marmer.Sehingga akibat beban yang diberikan terjadi perubahan gradasi agregat sehingga butiran yang lebih kecil masuk 
dan mengisi rongga yang ada.Selain itu mortar yang ada dalam campuran bekerja lebih baik dengan mengisi ruang/rongga sehingga campuran menjadi lebih padat.

\section{b. Voids In Mineral Aggregate( VMA )}

Voids in mineral agregat adalah rongga yang ada diantara agregat dalam campuran yang telah dipadatkan termasuk yang terisi aspal. VMA dinyatakan dala persen yang digunakan untuk menampung aspal. Faktor-faktor yang mempengaruhi nilai VMA antara lain adalah gradasi agregat, kadar aspal, kadar kondisi ini membuat aspal yang ada mengisi rongga antar antar agregat sehingga rongga tersebut menjadi lebih kecil. Pada campuran dengan variasi I hingga variasi IV memberikan tren peningkatan nilai VMA., sebab persen limbah pecahan marmer yang digunakan makin berkurang sebagai agregat kasar makin berkuran sehingga rongga dalam campuran menjadi lebih besar. Sebaliknya pada campuran variasi V terjadi penurunan nila VMA. Hal ini dimungkinkan adanya batuan yang pecah/hancur menjadi butiran yang lebih kecil ( degradasi agregat ) akibat beban yang diberikan, sehingga butiran tersebut mengisi rongga dalam campuran.

\section{c. Voids In Mix ( VIM )}

Voids in mix menyatakan besarnya persen rongga dalam campuran yang telah dipadatkan dimana nilai VIM dapat mempengaruhi kekedapan suatu campuran terhadap air dan udara. Besarnya nilai VIM dipengaruhi oleh kadar aspal, gradasi agregat energy dan temperatur pemadatan. Semakin tinggi nilai VIM maka campuran tersebut mempunyai presentase rongga yang semakin besar dan campuran akan bersifat porous sehingga campuran menjadi kurang rapat dan tiak kedap. Rongga yang banyak akan berpengaruh terhadap kebutuhan akan aspal dan kinerja campuran, karena udara akan dan air akan mudah masuk ke dalam rongga tersebut dan menyebabkan aspal mudah teroksidasi dan sehingga lapis perkerasan akan mudah retak.

Oleh Departemen Pekerjaan Umun ( 2010 ) menetapkan spesifikasi teknis bahwa nilai VIM pada pekerjaan dengan campuran HRS-BC adalah 3\% sampai 6\%. Hubungan kondisi pada setiap variasi campuran terhadap voids in mineral aggregate kondisi KAO telah disajikan dalam Tabel 4.3

\section{d. Voids Filled with Asphalt( VFA )}

Voids filled with asphalt mengindikasikan besarnya persen rongga dalam campuran yang dapat terisi oleh aspal setelah dipadatkan. Dimana nila VFA tersebut dapat menentukan keawetan suatu campuran. Nilai VFA dipengaruhi oleh kadar aspal, gradasi agregat, temperatur dan energi pemadatan. Nilai VFA yang tinggi mengidikasikan rongga yang dapat terisi oleh aspal lebih banyak dan rongga menjadi lebih kecil sehingga aspal yang dapat menyelimuti agregat akan lebih tebal dan campuran sulit untiuk dimasuki oleh air dan udara. Sebaliknya, bila VFA lebih kecil, rongga yang terisi oleh aspal lebih sedikit dan rongga dalam campuran lebih besar dan campuran miudah dimasuki oleh udara dan air sehingga menyebabkan campuran tidak padat. Namun jika VFA terlalu tinggi, akan memberikan kadar aspal yang berlebihan sehingga campuran akan mudah mengalami bledding. Oleh sebab itu, VFA dibatasi oleh VIM. 
Faktor yang mempengaruhi nilai VFA adalah kadar aspal, gradasi campuran dan energy pada saat pemadatan.

Departemen Pekerjaan Umum ( 2010 ) menetapkan spesifikasi teknis bahwa nilai VFA pada pekerjaan dengan campuran HRS-BC minimal 68\%. Hubungan kondisi setiap variasi campuran terhadap nilai voids filled with pada KAO telah disajikan dalam Tabel 4.3

\section{Pengujian Marshall immersion}

Dari pengujian tekan Marshall (Marshall Compression) terhadap masing-masing variasi campuran dengan peredaman selama $1 / 2$ Jam dan 24 jam pada suhu $60^{\circ} \mathrm{C}$, diperoleh hasil pengujian yang dapat dilihat pada Tabel 4.4. Nilai-nilai tersebut merupakan rata-rata dari hasil pengujian terhadap 3 benda uji ( triplo ) pada masing-masing variasi campuran.

Tabel 4.4 Hasil uji marshall immersion selama $1 / 2$ jam pada KAO.

\begin{tabular}{|c|c|c|c|c|c|c|c|}
\hline \multirow{2}{*}{ No. } & \multirow{2}{*}{$\begin{array}{c}\text { Karakteristik } \\
\text { Marsall }\end{array}$} & \multirow{2}{*}{ Satuan } & \multicolumn{5}{|c|}{ Variasi Campuran } \\
\cline { 4 - 8 } & & $\mathrm{kg}$ & 1242 & 1285 & 1321 & 1351 & 1334 \\
\hline 1. & Stability & $\mathrm{mm}$ & 3,4 & 3,6 & 3,77 & 3,93 & 4,0 \\
\hline 2. & Flow & $\mathrm{m}$ & & & & & \\
\hline 3. & $M Q$ & $\mathrm{~kg} / \mathrm{mm}$ & 365,15 & 360,32 & 351,95 & 346,34 & 333,51 \\
\hline
\end{tabular}

Tabel 4.5 Hasil uji marshall immersion seelama 24 jam pada KAO.

\begin{tabular}{|c|c|c|l|c|c|c|c|}
\hline \multirow{2}{*}{ No. } & \multirow{2}{*}{$\begin{array}{c}\text { Karak-teristik } \\
\text { Marsall }\end{array}$} & \multirow{2}{*}{ Sat. } & \multicolumn{5}{|c|}{ Variasi Campuran } \\
\cline { 4 - 8 } & & & I & II & III & IV & V \\
\hline 1. & Stability & $\mathrm{kg}$ & 1187 & 1239 & 1286 & 1322 & 1305 \\
\hline 2. & Flow & $\mathrm{mm}$ & 3,5 & 3,67 & 3,87 & 4,03 & 4,10 \\
\hline 3. & $M Q$ & $\mathrm{~kg} / \mathrm{mm}$ & 339,23 & 337,42 & 334,00 & 327,84 & 319,14 \\
\hline
\end{tabular}

Dari pengujian tekan Marshall ( Marshall Compression ) dengan lama peredaman 1/2 jam dan 24 jam diperoleh nilai stabilitas yang dihasilkan oleh masing-masing variasi campuran. Dengan nilai-nilai tersebut dapat diperoleh nilai durabilitas campuran yaitu indeks kekuatan sisa 
campuran untuk menggambarkan keseluruhan hasil durabilitas masing-masing variasi campuran.Hasil pengujian tersebut disajikan pada Tabel 4.4 dan Tabel 4.5.

Campuran agregat-aspal panas yang akan digunakan sebagai bahan perkerasan perlu diuji durabilitasnya. Hal ini guna mengctahui sejauh mana tingkat ketahanan bahan tersebut terhadap kondisi yang akan terjadi dikemudian hari terhadap perkerasan seperti pengaruh iklim dan lingkungan maupun pembebanan oleh lalu lintas. Hal perlu diperhatikan adalah bagaimana kondisi ataupun karakteristik dari bahan yang digunakan dalam campuran sehingga mampu membentuk suatu campuran dengan durabilitas yang cukup mampu memberikan kinerja yang baik pada perkerasan selama masa pelayanan.Campuran yang ada diharapkan mampu bertahan terhadap air dan perubahan sifat aspal karena penguapan, oksidasi dan kontaminasi dari bahan bakar kendaraan.

Stabilitas mengindikasikan kemampuan campuran dalam menerima beban maksimum tanpa mengalami perubahan bentuk yang permanen yang dinyatakan dalam satuan beban $(\mathrm{kg})$. Nilai stabilitas dipengaruhi oleh beberapa faktor yaitugradasi agregat, bentuk agregat, kualitas agrcgat, teksur permukaan agregat, kadar aspal dalam campuran, energi dan temperatur pemadatan.

Departemen Pekerjaan Umum (2010) menetapkan spesifikasi teknis bahwa nilai stabilitas pada pekerjaan dengan campuran HRS-BC minimal $800 \mathrm{~kg}$.Hubungan kondisi pada setiap variasi campuran terhadap nilai stabilitas pada kondisi KAO telah disajikan dalam Tabel 4.4 dan Tabel 4.5.5 serta dapat dilihat pada Gambar 4.1

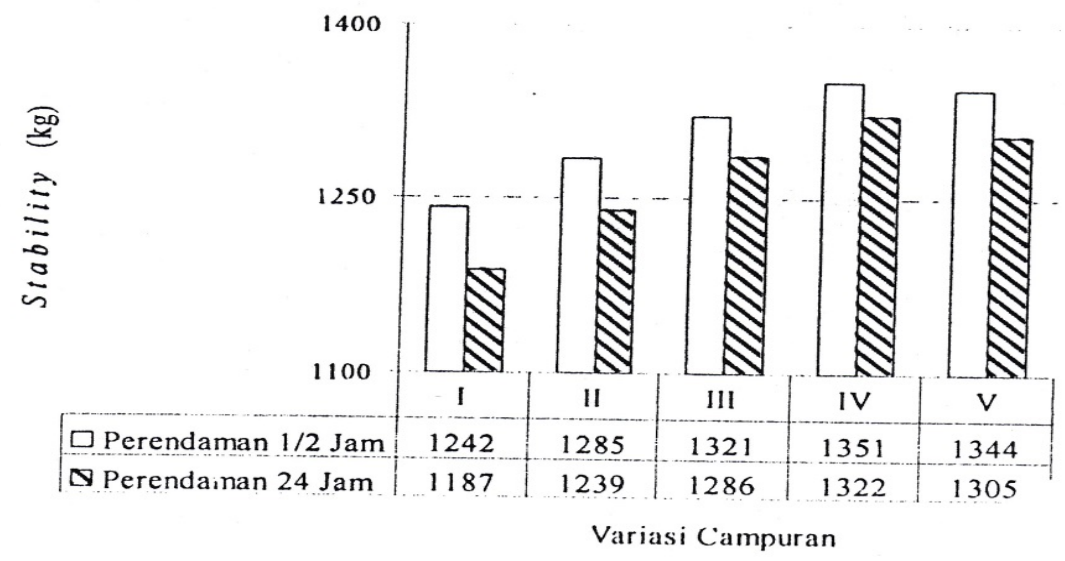

Gambar 4.1 Hubungan variasi campuran dengan nilai stabilitaspada kondisi KAO

Gambar 4.1 secara umum menunjukkan adanya peningkatan nilai stabilitas dengan bertambahnya kadar aspal hingga pada persentase kadar tertentu kemudian mengalami penurunan. Campuran dengan variasi I yang menggunakan $100 \%$ limbah pecahan marmer mempunyai stabilitas yang paling rendah jikadibandingkan campuran lainnya.Seperti diketahui bahwa pecahan marmermemiliki tekstur permukaan yang halus dan berdaya serap kecil. Dengan kondisi demikian, aspal tidak terserap dengan baik, sehingga dengan adanya perendaman pada suhu yang tinggi menyebabkan aspal yang tipis dan hanya melekat padapermukaan mengalami pelelehan dan akibat sifat hidropolyc batuan, ikatan aspaldan batuan mudah terlepas. Pada 
kondisi tersebut jika diberikan beban, maka ikatan dalam campuran mudah pecah, selain itu didukung pula oleh kepadatan campuran yang tinggi dan membuat campuran menjadi kaku dan getas.Oleh sebab itu stabilitas yang dimiliki juga sangat rendah.Pada campuran variasi II hingga variasi IV, yang menggunakan variasi campuran limbah pecahan marmer dan batu pecah sebagai agregat kasar, terlihat peningkatan nilai stabilitas.Hal ini didukung oleh kekcrasan yang dimiliki oleh limbah pecahan marmer yang ditandai dengan besaran nilai abrasi yaitu $25 \%$ lebih rendah dari batu pecah.Selain itu, pada dengan masuknya batu pecah dalam campuran, ikatan antara agregat dan aspal menjadi lebih baik dibandingkan dengan variasi I sehingga fungsi aspal sebagai pengikat agregat terutama agregat kasar menjadi lebih baik dan kekompakan campuran tetap terjaga.Pada variasi $\mathrm{V}$, mengalami penurunan nilai stabilitas. Hal_ ini karena variasi V menggunakan batu pecah 100\% sebagai agregat kasar, dimana batu pecah memiliki nilai abrasi dan absobsi yang Lebih besar yaitu 29,5\% untuk abrasi dan 1,640\% untuk absorbsi. Dengan pembebanan yang lebih besar menyebabkan batuan akan lebihh mudah pecah sehingga stabilitas campuran menurun. Kontribusi kekuatan campuran yang diberikan oleh pecahan marmer hanya terdapat pada campuran variasi IV dan tidak ada lagi dalam campuran variasi V. Selain in akibat abrasi yang tinggi, degradasi agregat mudah terjadi dan menyebabkan campuran menjadi lebih padat, kaku dan getas, sehingga bila mengalami pembebanan akan lebih mudah hancur. Oleh sebab itu stabilitas yang dihasilkan lebih rendah dari variasi sebelumnya.

Gambar 4.1 juga menunjukkan penurunan nilai stabilitas pada campuran setelah mengalami perendaman selama 24 jam. Jika dilakukan perendaman lebih lama lagi, nilai stabilitas akan lebih menurun. Hal ini diakibatkan oleh masuknya air ke dalam pori carnpuran dan mengganggu sifatg kohesif dari aspal dalam mengikat batuan. Kondisi ini dapat mempexlemah ikatan aspal karena air lebih mudah membasahi permukaan batuan daripada aspal sebab batuan mempunyai muatan kutub demikian pula dengan air dan aspal; tetapi muatan kutub air lebih kuat bila dibandingkan dengan aspal dalam mengikat batuan, sehingga akan mengganggun ikatan antar butian dan aspal. Pada campuran variasi I memberikan nilai stabilitas yang yang paling rendah dan penurunan stabilitas paling besar sebab lemahnya ikatan aspal dan batuan.

\section{Pengaruh perendaman terhadap flow campuran aspal panas pada berbagai variasi agregat.}

Flow man kelelehan mengindikasikan besarnya deformasi pada suatu campuran yang diakibatkan oleh adanya beban yang terjadi pada awal proses pembebanan hingga mencapai batas runtuh yang dinyatakan dalam satuan $\mathrm{mm}$. Nilai flow lapis perkerasan dipengaruhi oleh beberapa faktor, yaitu gradasi agregat, bentuk agregat, kualitas agregat, tekstur permukaan agregat, kadar aspal serta energi dan temperatur pemadatan. Nilai flow yang rendah mengindikasikan campuran yang kaku dan getas sehingga mudah retak apabila dibebani, sebaliknya campuran yang mempunyai nilai flow yang tinggi akan bersifat lebih plastis (lembek) sehingga mudah berubah bentuk saat mengalami pembebanan. 
Departemen Pekerjaan Umum (2010), menetapkan spesifikasi teknis bahwa nilai flow pada pekerjaan den gan campuran HRS-BC minimal 2,5 kg. Hubungan variasi campuran dengan nilai flow pada kondisi kadar aspal optimum telah disajikan dalam Tabel 4.4 dan Tabel 4.5 serta dapat dilihat pada Gambar 4.2.

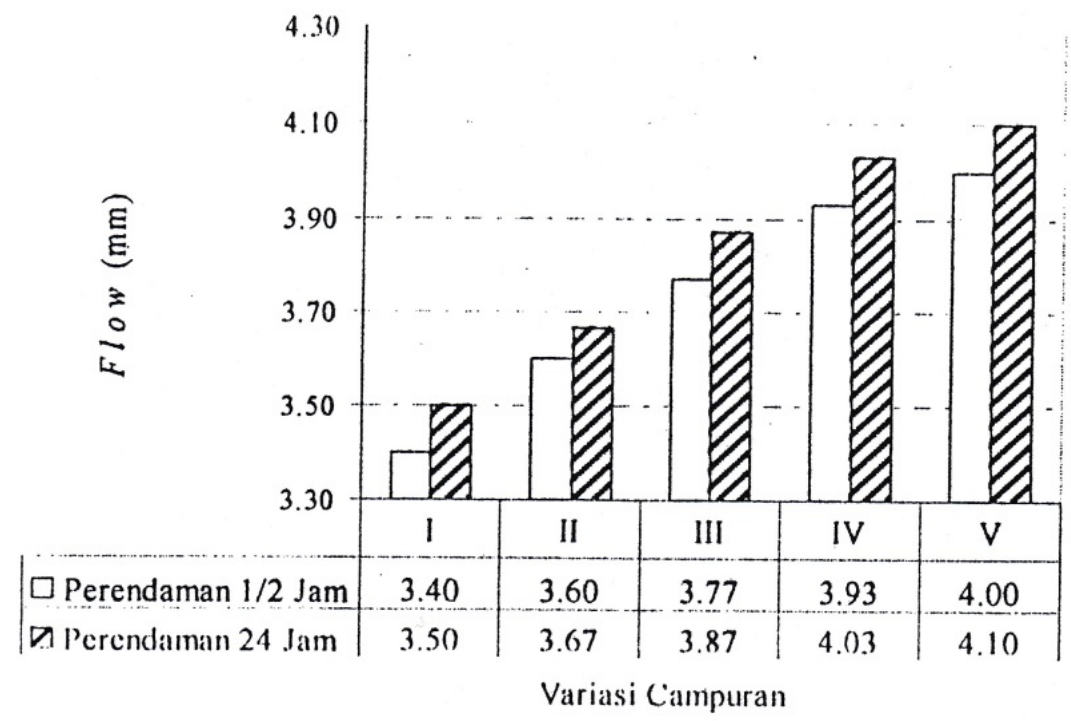

Gambar 4.2 Hubungan variasi campuran terhadap nilai flow pada kondisi KAO.

Dari gambar 4.2 terlihat adanya kenaikan nilai flow. bahwa dengan bertambahnya kadar aspal terjadi kenaikan kenaikan nilai flow pada setiap variasi campuran. Campuran variasi I memiliki nilai flow yang Lebih rendah dibandingkan campuran varisi II hingga variasi V dan terjadi nilai flow pada tiap variasi berikutnya.Hal ini disebabkan adanya pertambahan persentase batu pecah dalam campuran yang berarti adanya pertambahan rongga pada tiap variasi campuran.Seperti diketahui sebelumnya bahwa campuran vafiasi I menggunakan $100 \%$ limbah pecahan marmer sebagai aggregat kasar, dimana jenis batuan tcrsebut memiliki pori/rongga yang kecill schingga lekatan aspal terhadap batuan lebih tipis. Jika dibandingkan dengan campuran variasi I, rongga yang ada pada variasi II hingga V lebih besar sebab adanya pertambahan persentase batu pecah yang mempunyai pori yang lebih besar dan dapat menyerap aspal dengan baik, sehingga aspal yang dibutuhkan lebih banyak dan lekatan aspal lebih baik dan lebih tebal. Campuran variasi I mempunyai nilai flow yang rendah sehingga campuran cenderung menjadi lebih kaku dan mudah retak bila dibebani, sedangkan campuran variasi II hingga variasi $\mathrm{V}$ yang memiliki nilai flow yang lebih tinggi, maka campuran akan bersifat lebih plastis (lembek) sehingga mudah berubah bentuk atau deformasi akibat pembebanan.

Gambar 4.2 juga menunjukkan adanya peningkatan nilai flow pada campuran setelah mengalami perendaman selama 24 jam. Perendaman yang lebih lama akan semakin meningkatkan nilai flow pada campuran. Hal ini disebabkan kemampuan ikatan (sifat kohesif) dari agregat menurun setelah perendaman yang lebih lama pada suhu yang lebih tinggi.Kondisi 
demikian memyebakan campuran menjadi lebih lembek dan sangat mudah mengalami perubahan bentuk (deformasi).

\section{Pengaruh perendaman terhadap nilai Marshall quotlent campuran aspal panas} pada berbagai variasi agregat.

Marshall quation merupakan perbandingan antara stabilitas dan flow yang dinyatakan dalam satuan $\mathrm{kg} / \mathrm{mm}$ dan dapat mengindikasikan pendekatan terhadap kekakuan dan kelenturan suatu campuran. Campuran dengan nilai Marshall Quatlent yang rendah, akan lebih fleksibel, cenderung menjadi plastis dan lentur sehingga akan mudah mengalami perubahan bentukatau deformasi saat menerima beban lalu lintas, sedangkan campuran yang memiliki nilai Marshall Quotlent yang lebih tinggi akan cenderung lebih kaku dan kurang lentur sehingga mudah retak.

Departemen Pekerjaan Umum (2010) menetapkan spesifikasi teknis bahwa nilai Marshall quotlent panda pekterjaan clengan campuran HRS-BC minimal $250 \mathrm{~kg}$. Huhungan kondisi pada setiap variasi campuran terhadap dengan nilai Marshall Quotlent pada kondisi kadar aspal optimum telah disajikan dalam Tabel 4.4 dan Tabel 4.5 serta dapat dilihat pada Gambar 4.3.

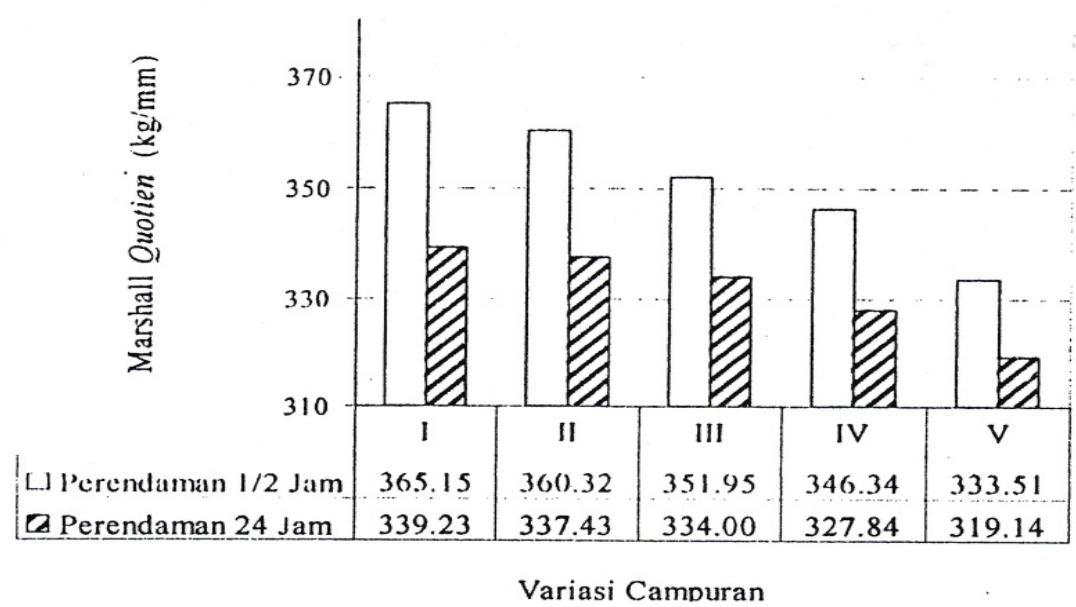

Gambar 4.3 Hubungan variasi canpuran terhadap nilai MQ pada kondisi KAO

Dari gambar 4.3 dapat dilihat adanya penurunan tiap campuran nilai Marshallquotien, karenaakan memberikan lapisan film yang lebih tebal sehingga fungsiaspal pada kadar aspal optimum bekerja dengan baik sehingga campuran akanlebih plastis. Campuran variasi I memiliki nilai Marshall quotienyang lebih besar dibandingkan dengan campuran variasi I1 hingga variasi V. Dengan demikiancampuran I lebih kaku dan kurang lentur dibandingkan campuran variasi II hingga variasi V yang bersifat lebih plastis. Kondisi ini didukung dengan 
sifat maupunkarakteristik dari batuan yang digunakan sebagai agregat kasar dan nilai densitypada variasi I yang lebih tinggi dibandingkan variasi lainnya.

\section{KESIMPULAN}

Berdasarkan hasil pengujian, analisa dan pembahasan yang telah dilakukan, maka dapat disimpulkan sebagai berikut :

1. Pengujian terhadap bahan perkerasan dalam hal ini agregat kasar (limbah pecahan marmer dan batu pecah), agregat halus dan filler yang dignakan sebagai bahan campuran aspal panas memenuhi spesifikasi yang disyaratkan oleh Departemen Pekerjaan Umum.

2. Penggunaan kombinasi limbah pecahan marmer dengan batu pecah sebagai agregat kasar pada campuran aspal panas jenis HRS-BC memberikan nilai kadar aspal optimum yang bervariasi pada setiap campuran. Kenaikan persen batu pecah dan penurunan limbah pecahan marmer dalam campuran diiringi dengan kenaikan kadar aspal optimum pada setiap variasi campuran berturut-turut sebagai berikut variasi I sebesar 5,8 \%; variasi II sebesar 5,94 \%; variasi III sebesar 6,04 ; variasi IV sebesar 6,1 \% dan variasi V sebesar $6,27 \%$.

3. Terjadinya penurunan stabilitas campuran seiring dengan penambahan waktu lama perendaman.

4. Jika diaplikasikan pada pekerjaan kontruksi di jalan sebaiknya digunakan campuran dengan variasi $50 \%$ batu pecah dan $50 \%$ limbah marmer atau variasi lainnya dengan prosentase limbah marmer lebih kecil dari $50 \%$. 